Autoimmune disease 239

Autologous stem cell transplantation 214, $221,230,255$

Autotransplantation 198

Bone marrow transplantation 188

Breast cancer, high-dose therapy 248

CD34+ cell mobilization 198

Cell-mediated immunotherapy 214

Conditioning regimen 230

-, nonablative 221

-, nonmyeloablative 221

CXCR4 198

Cytokine-mediated immunotherapy 214

Diffuse large B cell lymphoma 255
Becker, P.S. 188

Bensinger, W. 187, 230

Calandra, G. 198

Carella, A.M. 187, 206

Cascavilla, N. 206

Corsetti, M.T. 206

Daikeler, T. 239

DiPersio, J. 198

Flomenberg, N. 198

Kröger, N. 248
Lerma, E. 206

Maris, M.B. 221

Melillo, L. 206

Press, O. 230

Slavin, S. 214

Storb, R. 221

Sui, X. 230

Tyndall, A. 239

Zander, A.R. 248

Zinzani, P.L. 255

\title{
Subject Index Vol. 114, No. 4, 2005
}

Follicular lymphoma 255

Gene transfer 188

Graft-versus-lymphoma effects 221

Graft-versus-tumor effects 221

Hematological neoplasia 206

Hematopoietic cell transplantation 221

- progenitor cell mobilization 198

- stem cell transplantation 221

- - cells 188

High-dose chemoradiotherapy 214

- chemotherapy 248, 255

Immunotherapy 214

Insertional mutagenesis 188

Lentiviral vector 188
Leukemia 214

Lymphoma 214, 230

Mantle cell lymphoma 255

Metastatic solid tumors 214

Minimal residual disease 206, 214

Prognostic factors, breast cancer 248

Recombinant human interleukin 2214

Retroviral vector 188

SDF-1/CXCL12 198

Severe combined immunodeficiency disease 188

Tandem transplant 221 